\title{
High Density Culturing of Porcine Hepatocytes Immobilized on Nonwoven Polyurethane-Based Biomatrices
}

\author{
S.A. Pahernik ${ }^{a, 1}$ W.E. Thasler ${ }^{a}{ }^{1}$ M. Doser ${ }^{b}$ M.J. Gomez-Lechon ${ }^{c}$ \\ M.J. Castellc H. Planck ${ }^{b}$ H.G. Koebe ${ }^{a}$ \\ aDepartment of Surgery, Klinikum Grosshadern, University of Munich, and \\ bInstitute of Textile and Process Engineering, Department of Biomedical Engineering, Denkendorf, Germany; \\ cUnidad de Hepatología Experimental, Centro de Investigación, Hospital La Fe, Valencia, Spain
}

\section{Key Words}

Hepatocytes · Culturing, high density · Organs, artificial · Pig

\begin{abstract}
Objective: Hepatocytes are increasingly used as functional units in bioartificial liver devices. The objective of the present study was to investigate the feasibility of culturing porcine hepatocytes in high density on a novel polyurethane-based nonwoven three-dimensional matrix. We investigated (1) the optimal cell density within this culture configuration, (2) the maintenance of liverspecific morphology and cell functions over long-term periods and (3) the necessity to apply an additional extracellular matrix component (collagen gel). Methods: Nonwoven polyurethane matrices were manufactured by a specially developed fiber extrusion technology. Pig hepatocytes were cultured at various cell densities of 0.1 , $0.25,0.5,0.75,1$ and $2 \times 10^{6}$ cells $/ \mathrm{cm}^{2}$ on three-dimensional networks of nonwoven polyurethane matrices and cell adhesion as well as functional parameters (DNA of nonattached/attached cells, lactate dehydrogenase re-
\end{abstract}

Both authors contributed equally to the study. lease and cytochrome P450 activity) were determined. To assess the performance of cells within this configuration albumin and urea excretion was measured over 8 days. The potentially beneficial effect of an additional extracellular matrix configuration was evaluated by comparing the average albumin synthesis in groups of identical cell numbers. Results: The optimal cell density in this three-dimensional culture configuration was $1 \times$ $10^{6} \mathrm{cells} / \mathrm{cm}^{2}$. The functional capacity of hepatocytes was stable for 8 days at an average level of $53.7 \pm 5.6 \mathrm{ng} / \mathrm{h} / \mu \mathrm{g}$ DNA and of $1.8 \pm 0.14 \mu \mathrm{g} / \mathrm{h} / \mu \mathrm{g}$ DNA for albumin and urea excretion, respectively. The supplementation of an extracellular matrix configuration did not improve functional activity of cells. Average albumin synthesis was $35.6 \mathrm{ng} / \mathrm{h} / \mu \mathrm{g}$ DNA $(28.7,42.8)$ and $32.7 \mathrm{ng} / \mathrm{h} / \mu \mathrm{g}$ DNA $(23.4,49.2)$ for collagen-immobilized and control cul-

\section{Abbreviations used in this paper \\ DMEM Dulbecco's modified Eagle's medium \\ ECOD ethoxycoumarin deethylation \\ LDH lactate dehydrogenase}

\section{KARGER}

Fax +41613061234

E-Mail karger@karger.ch

www. karger.com

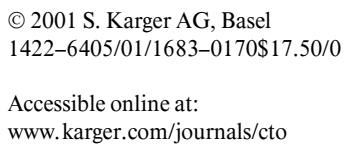

S.A. Pahernik, MD

Department of Urology, Johannes Gutenberg University of Mainz

Pettenkoferweg Gebäude 604, D-55101 Mainz (Germany)

Tel. +49 6131 171, Fax +49 6131232986

E-Mail pahernik@urologie.klinik.uni-mainz.de 
tures, respectively. Conclusion: The results of the study indicate that nonwoven polyurethane sheets supply a biocompatible support structure for functionally active high density cultures. Thus, nonwoven polyurethane matrices should be further investigated on with respect to their role in the development, optimization and design of bioartificial liver systems.

Copyright (C2001 S. Karger AG, Basel

\section{Introduction}

The development of bioartificial liver systems for acute and intermediate treatment of patients with fulminant hepatic failure remains a major biomedical challenge. In recent years research in this field has focussed on the use of cell-based artificial liver devices [Riordan et al., 1998]. In animal studies, treatment with extracorporeal liver support systems based on primary hepatocytes prolonged survival in experimentally induced liver failure [Takahashi et al., 1992; Sielaff et al., 1995; Flendrig et al., 1998]. First clinical studies suggested that hepatocytebased bioartificial liver devices can provide both, synthetic and detoxifying support for patients with fulminant hepatic failure [Rozga et al., 1993; Ellis et al., 1996; Watanabe et al., 1997].

In order to improve the efficacy of bioartificial liver support systems, a variety of devices have been suggested for the treatment of liver failure. Cell culture configurations employed for this purpose include cells attached to collagen-coated microcarriers [Kong et al., 1996], cells embedded in collagen matrices in hollow fiber systems [Nyberg et al., 1993], the sandwich configurations [Dunn et al., 1989] with its extended versions for high density culturing such as micropattering of hepatocytes [Bhatia et al., 1994] or full-scale flat membrane bioreactors [De Bartolo et al., 2000], three-dimensionally woven structures of capillaries [Gerlach et al., 1994] and nonwoven polyester matrices [Flendrig et al., 1997].

Since large amounts of viable cells are probably necessary to supply patients with external hepatic support during liver failure, one of the main research topics in this field focusses on three-dimensionally high density culturing of cells in an optimized reactor configuration [Flendrig et al., 1998]. The influence of the culture configuration on cells has to be investigated to effectively improve the design of bioreactors. Research in this field among others has to address key objectives such as biocompatibility, practicability and stability with respect to the bioreactor configuration. In addition, the maintenance of functional activity of liver cells in the selected culture configuration as well as mass transport considerations have important implications in the development of bioartificial liver devices.

The objective of this study was to investigate the feasibility of culturing porcine hepatocytes at high density on a novel polyurethane-based nonwoven three-dimensional matrix. To address this issue, we investigated the maximum cell density within this culture configuration that still allowed the maintenance of cell viability and specific hepatic functions over 8 days. We were further interested to find out whether this system would benefit from an additional extracellular matrix added to the cells and potentially resulting in an improved expression of a differentiated cell phenotype. The results of the study show that nonwoven polyurethane sheets are a feasible biocompatible support for functional, three-dimensional hepatocyte cultures and have important implications for the development, optimization and design of bioartificial liver systems.

\section{Material and Methods}

\section{Nonwoven Polyurethane Matrices}

Nonwoven polyurethane matrices were manufactured from polyurethane (Tecoflex ${ }^{\mathrm{TM}}$ EG 85A, Thermedics, Woburn, Mass., USA) by a fiber extrusion technology. Briefly, melted polymer is extruded through capillaries forming microfibers which have been laid down on a conveyor belt to a nonwoven structure. The thickness of the polyurethane matrices was $2 \mathrm{~mm}$ with a microfiber thickness of 20 $60 \mu \mathrm{m}$ (fig. 1A). The pore volume was $70 \%$, the diameter and the depth of the pores were 10-200 and up to $500 \mu \mathrm{m}$, respectively. The nonwoven matrices were cut into round circles with a diameter of $20 \mathrm{~mm}$ and afterwards glued to the culture dishes with a $0.1-\mathrm{ml}$ collagen solution ( $0.1 \mathrm{ml}$ collagen type I dissolved in Dulbecco's modified Eagle's medium, DMEM). The dishes were sterilized by $\gamma$-irradiation prior to use.

\section{Cell Isolation and Culturing of Hepatocytes}

Hepatocytes were isolated from slaughtered Landrace piglets (both sexes, 4-8 weeks old, weighing $25-35 \mathrm{~kg}$ ) as described previously [Koebe et al., 1995]. Cell viability of hepatocytes after density gradient purification was assessed by trypan blue exclusion and, in addition, verified by DNA and total protein measurements. Prior to cell culturing, the nonwoven polyurethane matrices were incubated with culture medium. After removing the medium from the matrices cells were seeded on top of the nonwoven matrices at a final density of $0.1,0.25,0.5,0.75,1$ and $2 \times 10^{6}$ cells $/ \mathrm{cm}^{2}$. For investigations on long-term performance of cell cultures in terms of functional activity and morphological integrity, cells were cultured at a cell density of $1 \times 10^{6} \mathrm{cells} / \mathrm{cm}^{2}$. To investigate the influence of an added collagen gel matrix on cell performance, collagen $(0.5 \mathrm{ml}, 0.5 \mathrm{mg} / \mathrm{ml})$ was added at $4{ }^{\circ} \mathrm{C} 2 \mathrm{~h}$ after seeding of cells [Yarmush et al., 1992a]. Type I collagen for coating of culture matrices was prepared from rat tail 
Fig. 1. Scanning electron micrographs of nonwoven polyurethane-based matrices. A Structure of nonwoven polyurethane matrices consisting of a framework of microfibers. The microfiber thickness varies between 20 and $60 \mu \mathrm{m}$. B Matrices seeded with hepatocytes 3 days after onset of culture. Hepatocytes are embedded in pores in between the microfibers exhibiting an endogenously generated microenvironment. Magnification: $\times 500$. The left upper panel shows a single hepatocyte at a higher magnitude $(\times 2,000)$ being in contact with neighboring cells with intercellular filaments presumably extracellular matrix components.
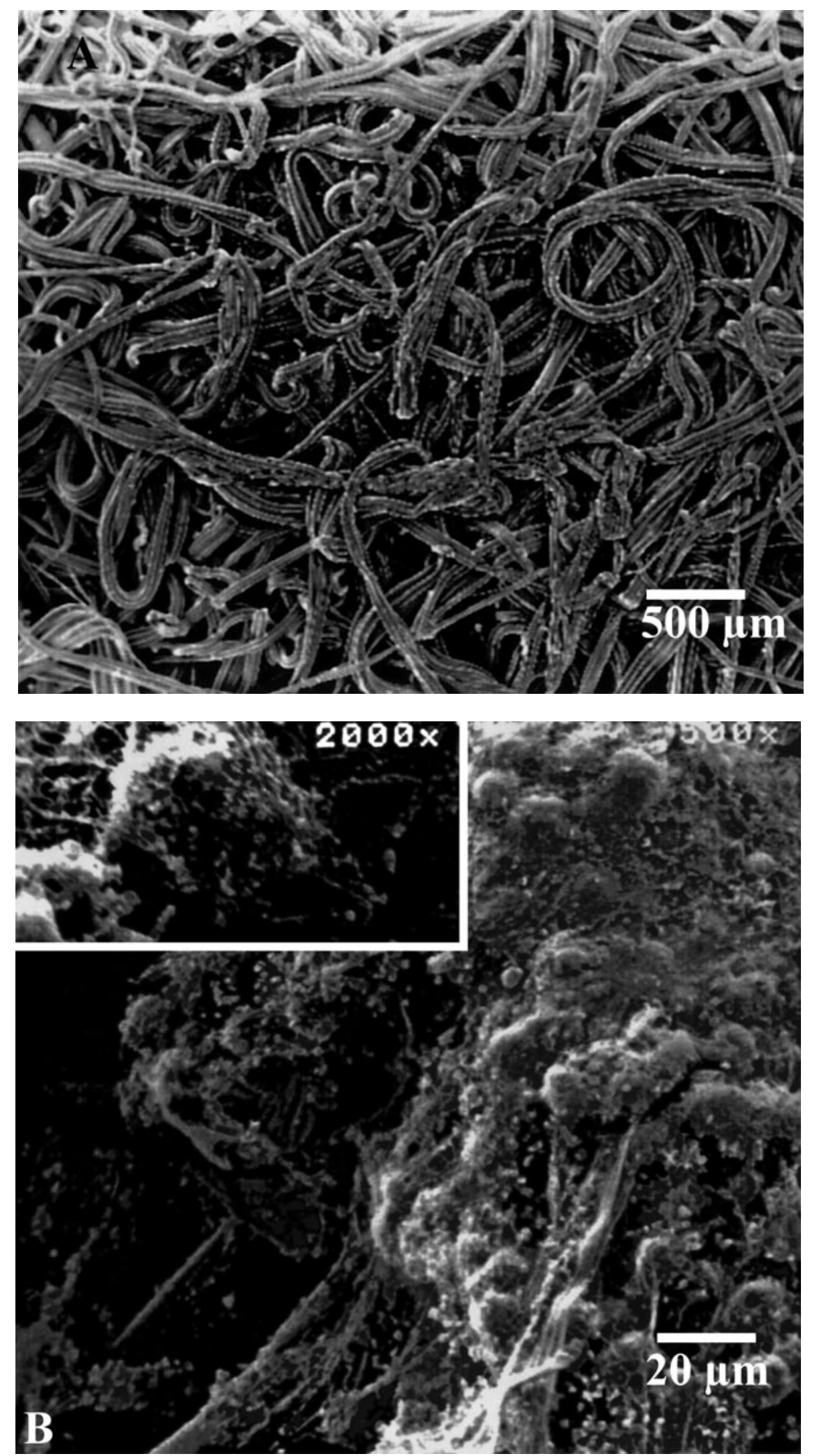
tendons as described earlier in detail [Koebe et al., 1994]. Cells were cultured at $37^{\circ} \mathrm{C}$ and $40 \%$ oxygen atmosphere in culture medium consisting of phenol red-free DMEM supplemented with insulin $(125 \mathrm{mU} / \mathrm{ml})$, hydrocortisone $(60 \mathrm{ng} / \mathrm{ml})$, glucagon $(10 \mathrm{ng} / \mathrm{ml})$, gentamycin $(100 \mu \mathrm{g} / \mathrm{ml})$, penicillin $(100 \mathrm{mU} / \mathrm{ml})$ and $5 \%$ fetal calf serum (FCS) for the first $24 \mathrm{~h}$. Serum-free medium was changed daily, collected and stored at $-40^{\circ} \mathrm{C}$ before analysis.

\section{Scanning Electron Microscopy}

For scanning electron microscopy purposes hepatocytes were held for $90 \mathrm{~min}$ in Soerensen phosphate buffer containing $6.25 \% \mathrm{glu}-$ taraldehyde $(\mathrm{v} / \mathrm{v})$ and then washed in sacharose containing Soerensen phosphate buffer. Ultrastructure of cells within nonwoven polyurethane matrices was assessed by a scanning electron microscope (Zeiss DSM 950). Small pieces of the seeded material were freezedried in a cryopreparation chamber (Paloron LT 7400) and coated in a sputter coated with a layer of gold/palladium.

\section{Cell Attachment}

Cell attachment to nonwoven polyurethane matrices was quantified $2 \mathrm{~h}$ after onset of culture. Cultures were washed carefully with phosphate-buffered saline (PBS) containing $137 \mathrm{mM} \mathrm{NaCl}, 7.9 \mathrm{mM}$ $\mathrm{Na}_{2} \mathrm{HPO}_{4}, 1.5 \mathrm{mMKH} \mathrm{KH}_{2} \mathrm{PO}_{4}$ and $2.7 \mathrm{mM} \mathrm{KCl}$ (pH 7.4). The supernatant was centrifuged at $1,000 \mathrm{~g}$, the supernatant was removed and cells and cultures frozen at $-80^{\circ} \mathrm{C}$. Cells were homogenized osmotically by adding aqua ad injectabilia and successive 2 -fold thawing and freezing. For the determination of cell attachment rates, total DNA content was measured from matrix-attached and nonattached cells in the supernatant. DNA content of cells was analyzed fluorometrically using a multiwell plate scanner fluorometer $\left(1_{\mathrm{ex}}=355 \mathrm{~nm}\right.$; $1_{\mathrm{em}}=460 \mathrm{~nm}$; Titertek Fluoroscan, Labsystems, Helsinki, Finland) as previously described [Koebe et al., 1995]. The attachment rate was calculated (attached cells/attached and nonattached cells $\times 100 \%$ ) and expressed as percentage of attached cells.

\section{Assays}

The activity of cytochrome P450-dependent ethoxycoumarin deethylation (ECOD) was measured in intact cells fluorometrically as described previously after adding $100 \mu M$ 7-ethoxycoumarin substrate to the cells [Koebe et al., 1995]. Albumin secretion into the supernatant medium was assayed immunologically as described by the manufacturer (Dako Diagnostika, Hamburg, Germany). Extinction was measured at $450 \mathrm{~nm}$ with a Titertek Multiscan Plus Reader MK II from Flow Laboratories (Meckenheim, Germany). Lactate dehydrogenase (LDH) was measured colorimetrically in the frame of routine clinical diagnostics.

\section{Statistical Analysis}

Data are expressed as mean \pm standard deviation $(n=6)$. Statistical analysis among groups was performed by using one-way ANOVA on ranks followed by a post-hoc Student-Newman-Keuls test. Statistical analysis within groups was performed by Friedman repeated measurements ANOVA on ranks followed by the post-hoc Dunn test. In case of a lack of a normal distribution, data are given as medians and 25 and $75 \%$ quartiles and statistical analysis was performed using the Mann-Whitney rank sum test. Statistical significance was assigned for $\mathrm{p}$ values less than 0.05 .

High-Density Culturing of Hepatocytes

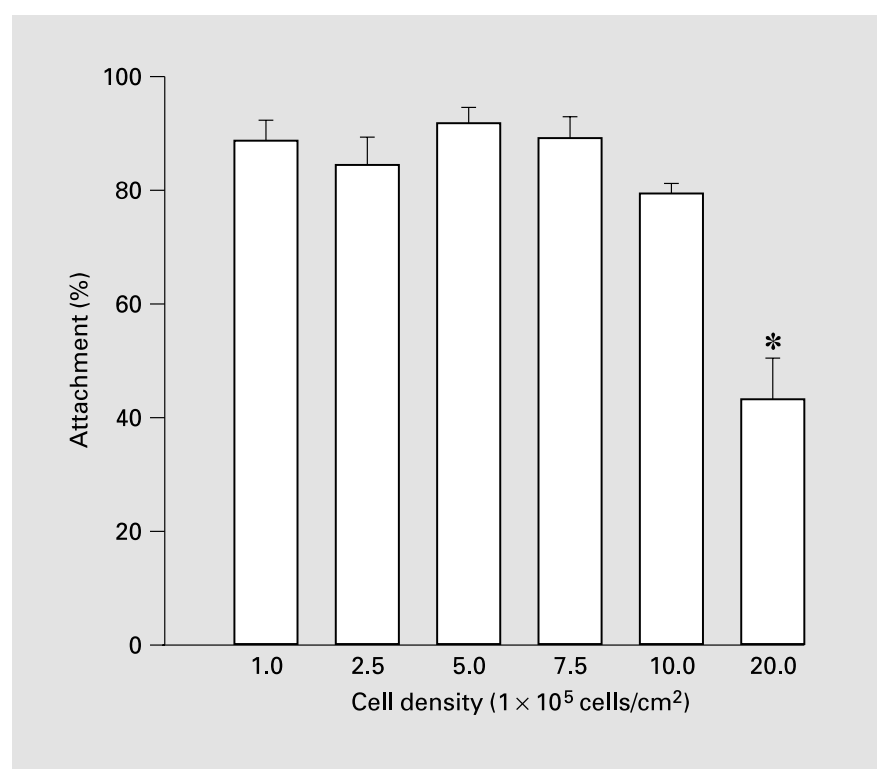

Fig. 2. Attachment rates of hepatocytes as a function of cell density. Efficiency of adhesion of cells to the nonwoven polyurethane matrices was quantified $2 \mathrm{~h}$ after onset of culture. Attachment rates are expressed as percentage of nonattached cells to the total amount of cells and given as mean $\pm \mathrm{SD}\left(\mathrm{n}=6 ;^{*} \mathrm{p}<0.05\right.$ for $20 \times 10^{5}$ cells/ $\mathrm{cm}^{2}$ vs. all other groups).

\section{Results}

\section{Nonwoven Polyurethane Matrices}

The microenvironment of the three-dimensional polyurethane matrix configuration was defined by the thickness of microfibers and the configuration of pores and channels within the matrix. Pore dimensions (volume: $70 \%$, diameter: $10-200 \mu \mathrm{m})$ were selected in order to enable penetration and seeding of cells into the pores without passing through the matrix. Hepatocytes were embedded in pores between the microfibers and produced their own extracellular matrix. Within 3 days, cells were immobilized in a network of intercellular filaments (fig. 1B).

\section{High Density Cultures of Hepatocytes}

To investigate the maximal cell amount to be cultured on the nonwoven polyurethane matrices, we measured adhesion rates of cells to the matrix within the first $2 \mathrm{~h}$ after the onset of culture. Attachment rates varied from 80 to $90 \%$ independent from administered cell density (from 0.1 to $1 \times 10^{6} \mathrm{cells} / \mathrm{cm}^{2}$ ). However, when $2 \times 10^{6}$ cells $/ \mathrm{cm}^{2}$ were inoculated onto the matrix, attachment rate was reduced to $43.6 \pm 6.9 \%$ (fig. 2). Likewise, cellu- 


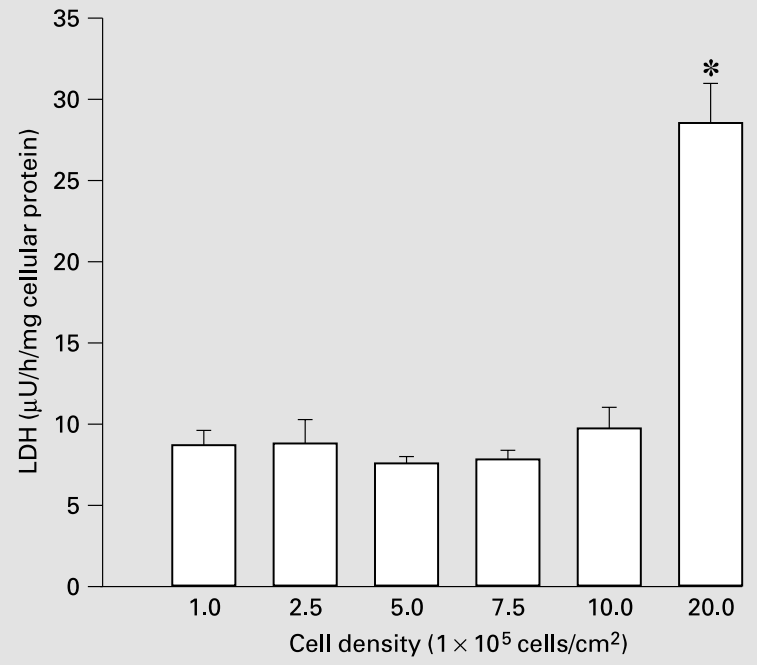

Fig. 3. LDH release of hepatocytes as a function of cell density. LDH as a parameter for cellular integrity of hepatocytes was measured from the supernatant medium $24 \mathrm{~h}$ after onset of culture. LDH is given as mean $\pm \mathrm{SD}\left(\mathrm{n}=6 ;{ }^{*} \mathrm{p}<0.05\right.$ for $20 \times 10^{5}$ cells $/ \mathrm{cm}^{2}$ vs. all other groups).

lar integrity of hepatocytes during the first $24 \mathrm{~h}$ of culture was examined by the release of LDH into the supernatant medium. LDH release of hepatocytes varied from $7.6 \pm$ 0.5 to $9.8 \pm 1.4 \mu \mathrm{U} / \mathrm{h} / \mathrm{mg}$ cellular protein for the cultured cell densities (from 0.1 to $1 \times 10^{6}$ cells $/ \mathrm{cm}^{2}$ ). When cells were cultured at a cell density of $2 \times 10^{6} \mathrm{cells} / \mathrm{cm}^{2}$ the release of $\mathrm{LDH}$ was elevated to $28.6 \pm 2.4 \mu \mathrm{U} / \mathrm{h} / \mathrm{mg}$ cellular protein (fig. 3). The increase in cell density showed an influence on the functional activity of cells. Cytochrome P450-dependent activity of ECOD increased from $1.1 \pm$ $0.2 \mathrm{pmol} / \mathrm{min} / \mu \mathrm{g}$ DNA for the $0.1 \times 10^{6} \mathrm{cells} / \mathrm{cm}^{2}$ group to $2.6 \pm 0.3 \mathrm{pmol} / \mathrm{min} / \mu \mathrm{g}$ DNA for the $0.25 \times 10^{6}$ cells $/$ $\mathrm{cm}^{2}$ group and reached maximal values of approximately $5 \mathrm{pmol} / \mathrm{min} / \mu \mathrm{g}$ DNA for the $0.5,0.75$ and $1 \times 10^{6}$ cells $/$ $\mathrm{cm}^{2}$ groups. At a higher cell concentration $\left(2 \times 10^{6}\right.$ cells/ $\mathrm{cm}^{2}$ ) ECOD was reduced to $1.2 \pm 0.2 \mathrm{pmol} / \mathrm{min} / \mu \mathrm{g}$ DNA (fig. 4).

\section{Long-Term Performance of Cultures within \\ Polyurethane Matrices}

For investigating functional performance of cells the daily albumin and urea secretion of cells was determined. Albumin excretion increased from $14.0 \pm 3.7 \mathrm{ng} / \mathrm{h} / \mu \mathrm{g}$ DNA at day 1 of culture to $25.8 \pm 4.1 \mathrm{ng} / \mathrm{h} / \mu \mathrm{g}$ DNA at

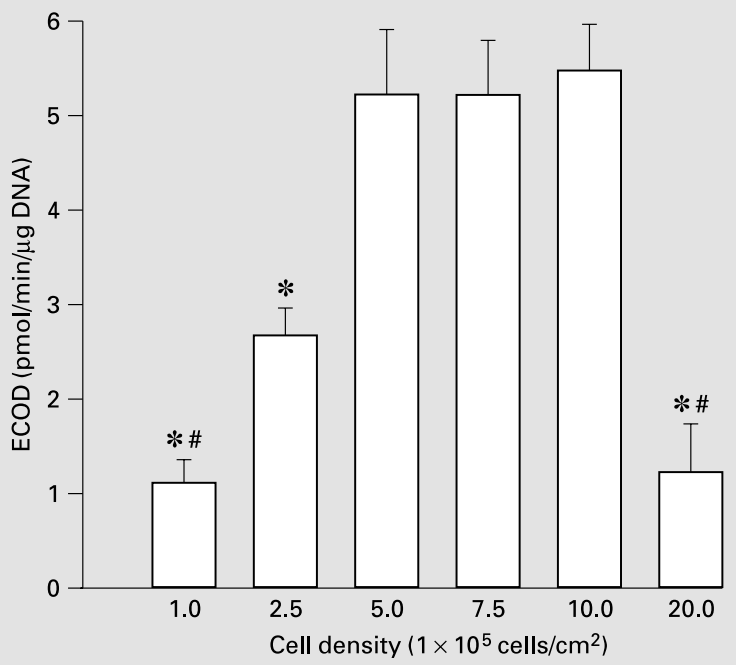

Fig. 4. Functional activity of hepatocytes as a function of cell density. Hepatic metabolic function was assessed by determining cytochrome P450-dependent activity of ECOD. ECOD is given as mean $\pm \mathrm{SD}\left(\mathrm{n}=6 ; * \mathrm{p}<0.05\right.$ vs. $5 \times 10^{5}$ cells $/ \mathrm{cm}^{2}, 7.5 \times 10^{5}$ cells $/ \mathrm{cm}^{2}$ $10 \times 10^{5}$ cells $/ \mathrm{cm}^{2} ; \# \mathrm{p}<0.05$ vs. $2.5 \times 10^{5}$ cells $/ \mathrm{cm}^{2}$.

day 2 of culture. Over the following investigational period (day 3-8), albumin excretion was stable at an average level of $53.7 \pm 5.6 \mathrm{ng} / \mathrm{h} / \mu \mathrm{g}$ DNA (fig. 5). Urea excretion showed stable values at an average level of $1.8 \pm 0.14$ $\mu \mathrm{g} / \mathrm{h} / \mu \mathrm{g}$ DNA (fig. 5).

\section{Influence of an Additional Extracellular Matrix}

To compare the influence of a collagen gel layer added on top of the cultures 1 day after seeding, the mean albumin excretion in subsequent cultures was averaged between culture day 1 and 10 . Mean albumin secretion was $35.6 \mathrm{ng} / \mathrm{h} / \mu \mathrm{g}(28.7,42.8)$ and $32.7 \mathrm{ng} / \mathrm{h} / \mu \mathrm{g}(23.4,49.2)$ DNA for cells cultured on nonwoven polyurethane matrices alone and with collagen, respectively (median, 25 and $75 \%$ quartiles) (fig. 6).

\section{Discussion}

The development of hybrid bioreactor devices as bioartificial liver support systems is gaining more and more attention [Rozga and Demetriou, 1995]. For the clinical treatment of hepatic failure large numbers of functionally active hepatocytes in high-density culture 


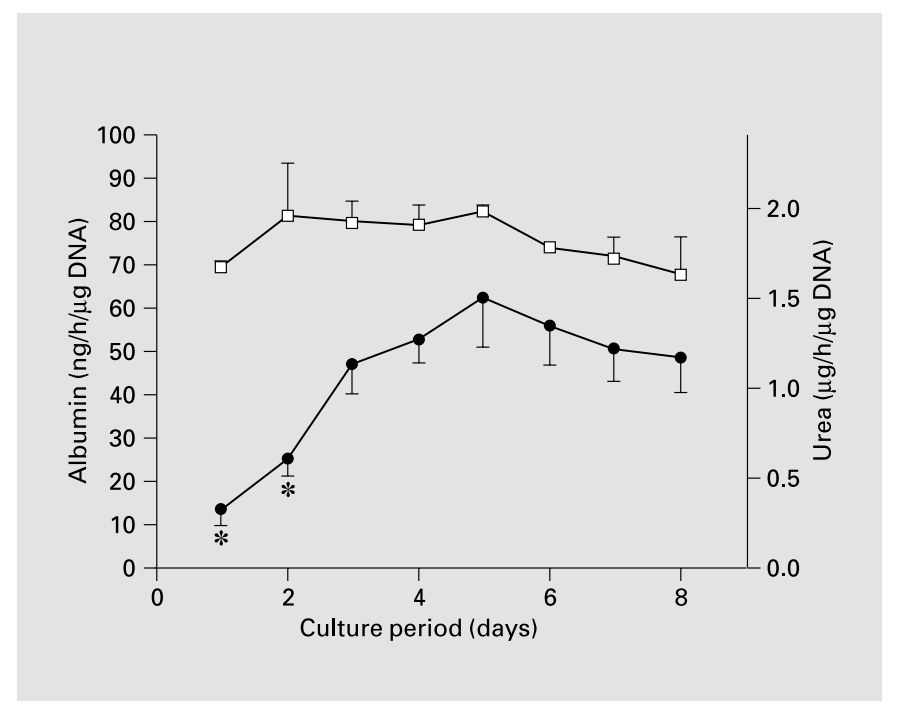

Fig. 5. Long-term functional performance of cultures within polyurethane matrices. Functional capacity of cells over long-term periods was assessed by determining albumin $(\bullet)$ and urea $(\square)$ excretion of cells. Data are given as mean $\pm \operatorname{SD}\left(n=6 ;{ }^{*} \mathrm{p}<0.05\right.$ day 1,2 vs. day $3-8)$.

configuration have to be employed as functional units of such devices [Nyberg et al., 1992]. In order to optimize the required cell number per volume ratio, hepatocytes in bioreactors cannot be cultured in a standard monolayer in vitro configuration. New concepts of multilevel cell culture packing inside of bioreactors have to increase the amount of cells per volume. Thus, special emphasis should be laid on easy to apply techniques as well as on stability of functional integrity of cells cultured therein. One of the concepts for the design of such devices includes direct immobilization of cells within artificial materials suitable to support functional and morphological characteristics of hepatocytes. Synthetic materials have been used with varying success as three-dimensional cell matrices such as reticulated polyvinyl formal resins [Ohshima et al., 1997; Miyoshi et al., 1998] or nonwoven polyester sheets [Flendrig et al., 1997; Naruse et al., 1998]. In the present study we used nonwoven polyurethane because of its well-known biocompatibility and its collagen-like structure that has led to a variety of experiments with other cell types in the past, particularly with endothelial cells for the inner lining of vascular prosthesis materials [Sigot-Luizard et al., 1993]. The processing of nonwoven matrices was optimized in a number of screen-

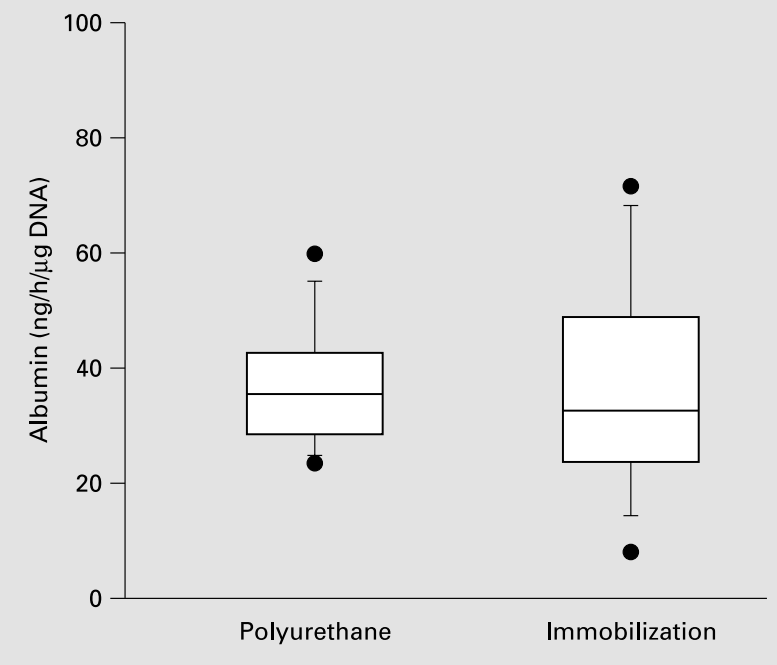

Fig. 6. Influence of additive extracellular matrix proteins. Functional capacity of cells over long-term periods was assessed by averaging the albumin excretion of cells during the first 10 days of culture. Albumin is illustrated as box plots.

ing experiments in order to create a compatible microenvironment for hepatocytes. Pore geometry within the polyurethane network with a pore diameter of $200 \mu \mathrm{m}$ seemed to be of crucial importance to support morphologically stable and functionally active hepatocyte cultures. The polyurethane matrices served as culture carrier to create a three-dimensional microenvironment. Scanning electron-microscopic investigations revealed that nonwoven polyurethane matrices provide a framework for high density hepatocyte immobilization. After seeding, optimized pore sizes allowed cells to organize into small aggregates on and between the microfibers. Hepatocytes seemed to establish intercellular contact via extracellular matrix proteins. Cells seeded on nonwoven polyurethane matrices did not need an additional layer of extracellular matrix components for attachment to the matrix and did not seem to improve their function when compared to untreated cells. These data are surprising, since hepatocytes embedded in a collagen matrix have been shown to benefit in terms of morphological and functional performance when compared to single gel surface cultures [Yarmush et al., 1992a].

This, in combination with the data obtained from scanning electron-microscopic investigation, suggests that 
hepatocytes cultured in this polyurethane microenvironment create their own extracellular matrix configuration during culture, in particular if they are cultured at high density. These observations are partially in agreement with a previous study showing that porcine hepatocytes attached to hydrophilic plastic surfaces alone did not differ from liver cells in extracellular matrix components such as collagen, laminin and fibronectin when compared for functional activity [Te Velde et al., 1995]. This could mean an important advantage for the ultimate design of hepatocyte-based bioreactors. The preparation of functional units is by far easier, if cells alone can be seeded without the aid of matrix additives and the system is better defined and safer to be used in man. Due to the orientation of cells within channels and pores of the threedimensional matrix, cells are mechanically protected from shear forces of fluids.

The aim of our present study was to investigate the feasibility of culturing porcine hepatocytes at high density on a novel polyurethane-based nonwoven three-dimensional matrix. The highest cell density in this culture configuration was $1 \times 10^{6}$ cells $/ \mathrm{cm}^{2}$. The attachment rate varied from 80 to $90 \%$ independently of the chosen cell density (from 0.1 to $1 \times 10^{6}$ cells $/ \mathrm{cm}^{2}$ ). For higher cell densities $\left(2 \times 10^{6}\right.$ cells $\left./ \mathrm{cm}^{2}\right)$ attachment rates to the culture carrier were drastically reduced and the LDH release of cells increased indicating cell damage. This could be due to a shortage of available oxygen in particular in the early phase of culture, since hepatocytes that have undergone an enzymatic cell isolation protocol do have an elevated need for oxygen [Foy et al., 1994]. Therefore, as suggested by other authors, we used a $40 \%$ oxygen atmosphere [Yanagi et al., 1998]. The optimal oxygen partial pressure to be administered for allowing even higher cell density with this culture technology remains to be determined in fur- ther studies. The metabolic function of hepatocytes seems to depend on the cell density in culture. For cell densities of $0.1 \times 10^{6}, 0.25 \times 10^{6}$ and $2 \times 10^{6}$ cells $/ \mathrm{cm}^{2}$ cytochrome P450-dependent ECOD activity was decreased compared to the $0.5,0.75$ and $1 \times 10^{6}$ cells $/ \mathrm{cm}^{2}$ groups. This could be explained by the scanning electron microscope investigations. Cells in the latter density groups created small hepatocyte aggregates interacting with each other and the three-dimensional polyurethane framework. This aggregation formation seemed to be crucial for cellular functionality.

The ability to maintain liver-specific cell morphology and functions over long-term periods has been claimed to be one of the crucuial requirements for the development of bioreactors for bioartificial liver devices [Yarmush et al., 1992b]. Urea synthesis was monitored as a parameter for detoxifying capacity of cells. At a cell density of $1 \times$ $10^{6}$ cells $/ \mathrm{cm}^{2}$ urea synthesis could be kept stable for the investigational period of 8 days. Likewise, after 2 days of culture albumin synthesis in this group was found to be stable over the following days.

In conclusion, nonwoven polyurethane sheets represent an easy to use and biocompatible support structure for the housing of functionally active hepatocyte cultures and could have important implications for the development, optimization and design of bioartificial liver devices.

\section{Acknowledgements}

The excellent and skillful assistance of Ursula Cramer, Katerina Kraijcikova and Marianne Kussmaul is much appreciated.

The study was supported by a grant from the European Community (Biomed 1, No. BMH-CT94-1097).

\section{References}

Bhatia, S.N., M. Toner, R.G. Tompkins, M.L. Yarmush (1994) Selective adhesion of hepatocytes on patterned surfaces. Ann NY Acad Sci 745 . 187-209.

De Bartolo, L., G. Jarosch-von Schweder, A. Haverich, A. Bader (2000) A novel full-scale flat membrane bioreactor utilizing porcine hepatocytes: Cell viability and tissue specific functions. Biotechnol Prog 16: 102-108.

Dunn, J.C., M.L. Yarmush, H.G. Koebe, R.G. Tompkins (1989) Hepatocyte function and extracellular matrix geometry: Long-term culture in a sandwich configuration. FASEB J 3: 174177.
Ellis, A.J., R.D. Hughes, J.A. Wendon, J. Dunne, P.G. Langley, J.H. Kelly, G.T. Gislason, N.L. Sussman, R. Williams (1996) Pilot-controlled trial of the extracorporeal liver assist device in acute liver failure. Hepatology 24: 1446-1451.

Flendrig, L.M., S.J. La, G.G. Jorning, A. Steenbeek, O.T. Karlsen, W.M. Bovee, N.C. Ladiges, V.A. Te Velde, R.A. Chamuleau (1997) In vitro evaluation of a novel bioreactor based on an integral oxygenator and a spirally wound nonwoven polyester matrix for hepatocyte culture as small aggregates. J Hepatol 26: 1379-1392.
Flendrig, L.M., M.A. Maas, J. Daalhuisen, N.C. Ladiges, S.J. La, V.A. Te Velte, R.A. Chamuleau (1998) Does the extent of the culture time of primary hepatocytes in a bioreactor affect the treatment efficacy of a bioartificial liver? Int J Artif Organs 21: 542-547.

Foy, B.D., A. Rotem, M. Toner, R.G. Tompkins, M.L. Yarmush (1994) A device to measure the oxygen uptake rate of attached cells: Importance in bioartificial organ design. Cell Transplant 3: 515-527. 
Gerlach, J., J. Encke, C. Muller, P. Neuhaus (1994) Zellkulturmodell für die Hepatozytenkultur in Bioreaktoren zur Nutzung ihres Metabolismus in hybriden Leberunterstützungssystemen. Zentralbl Chir 119: 334-340.

Koebe, H.G., S. Pahernik, P. Eyer, F.W. Schildberg (1994) Collagen gel immobilization: A useful cell culture technique for long-term metabolic studies on human hepatocytes. Xenobiotica 24: 95-107.

Koebe, H.G., S.A. Pahernik, M. Sproede, W.E. Thasler, F.W. Schildberg (1995) Porcine hepatocytes from slaughterhouse organs. An unlimited resource for bioartificial liver devices. ASAIO J 41: 189-193.

Kong, L.B., S. Chen, A.A. Demetriou, J. Rozga (1996) Matrix-induced liver cell aggregates (MILCA) for bioartificial liver use. Int J Artif Organs 19: 72-78.

Miyoshi, H., K. Ookawa, N. Ohshima (1998) Hepatocyte culture utilizing porous polyvinyl formal resin maintains long-term stable albumin secretion activity. J Biomater Sci Polym Ed 9 . 227-237.

Naruse, K., I. Nagashima, Y. Sakai, Y. Harihara, G.X. Jiang, M. Suzuki, T. Muto, M. Makuuchi (1998) Efficacy of a bioreactor filled with porcine hepatocytes immobilized on nonwoven fabric for ex vivo direct hemoperfusion treatment of liver failure in pigs. Artif Organs 22: 1031-1037.

Nyberg, S.L., R.A. Shatford, W.S. Hu, W.D. Payne, F.B. Cerra (1992) Hepatocyte culture systems for artificial liver support: Implications for critical care medicine (bioartificial liver support). Crit Care Med 20: 1157-1168.
Nyberg, S.L., K. Shirabe, M.V. Peshwa, T.D. Sielaff, P.L. Crotty, H.J. Mann, R.P. Remmel, W.D. Payne, W.S. Hu, F.B. Cerra (1993) Extracorporeal application of a gel-entrapment, bioartificial liver: Demonstration of drug metabolism and other biochemical functions. Cell Transplant 2: 441-452.

Ohshima, N., K. Yanagi, H. Miyoshi (1997) Packed-bed type reactor to attain high density culture of hepatocytes for use as a bioartificial liver. Artif Organs 21: 1169-1176.

Riordan, S.M., G.G. Skouteris, R. Williams (1998) Metabolic activity and clinical efficacy of animal and human hepatocytes in bioartificial liver support systems for acute liver failure. Int $\mathbf{J}$ Artif Organs 21: 312-318.

Rozga, J., A.A. Demetriou (1995) Artificial liver. Evolution and future perspectives. ASAIO J 41: $831-837$

Rozga, J., L. Podesta, E. LePage, A. Hoffman, E. Morsiani, L. Sher, G.M. Woolf, L. Makowka, A.A. Demetriou (1993) Control of cerebral oedema by total hepatectomy and extracorporeal liver support in fulminant hepatic failure. Lancet 342: 898-899.

Sielaff, T.D., M.Y. Hu, B. Amiot, M.D. Rollins, S. Rao, B. McGuire, J.R. Bloomer, W.S. Hu, F.B. Cerra (1995) Gel-entrapment bioartificial liver therapy in galactosamine hepatitis. J Surg Res 59: 179-184.

Sigot-Luizard, M.F., M. Sigot, R. Guidoin, M. King, W.W. von Maltzahn, R. Kowligi, R.C. Eberhart (1993) A novel microporous polyurethane blood conduit: Biocompatibility assessment of the UTA arterial prosthesis by an organo-typic culture technique. J Invest Surg 6: 251-271.
Takahashi, M., H. Matsue, M. Matsushita, K. Sato, M. Nishikawa, M. Koike, H. Noto, Y. Nakajima, J. Uchino, T. Komai (1992) Does a porcine hepatocyte hybrid artificial liver prolong the survival time of anhepatic rabbits? ASAIO J 38: M468-M472.

Te Velde, A., N.C. Ladiges, L.M. Flendrig, R.A. Chamuleau (1995) Functional activity of isolated pig hepatocytes attached to different extracellular matrix substrates. Implication or application of pig hepatocytes in a bioartificial liver. J Hepatol 23: 184-192.

Watanabe, F.D., C.J. Mullon, W.R. Hewitt, N Arkadopoulos, E. Kahaku, S. Eguchi, T. Khalili, W. Arnaout, C.R. Shackleton, J. Rozga, B. Solomon, A.A. Demetriou (1997) Clinical experience with a bioartificial liver in the treatment of severe liver failure. A phase I clinical trial. Ann Surg 225: 484-491.

Yanagi, K., H. Miyoshi, N. Ohshima (1998) Improvement of metabolic performance of hepatocytes cultured in vitro in a packed-bed reactor for use as a bioartificial liver. ASAIO J 44. M436-M440.

Yarmush, M.L., J.C. Dunn, R.G. Tompkins (1992b) Assessment of artificial liver support technology. Cell Transplant 1: 323-341.

Yarmush, M.L., M. Toner, J.C. Dunn, A. Rotem, A. Hubel, R.G. Tompkins (1992a) Hepatic tissue engineering. Development of critical technologies. Ann NY Acad Sci 665: 238-252. 